\title{
Manganese, nickel and strontium bioaccumulation in the tissues of the African sharptooth catfish, Clarias gariepinus from the Olifants River, Kruger National Park
}

\author{
Annemarié Avenant-Oldewage and Hazel Marx
}

\begin{abstract}
Avenant-Oldewage, Annemarié and Hazel Marx. 2000. Manganese, nickel and strontium bioaccumulation in the tissues of the African sharptooth catfish, Clarias gariepinus from the Olifants River, Kruger National Park. Koedoe 43(2): 17-33. Pretoria. 0075-6458.
\end{abstract}

\begin{abstract}
The gills, liver, muscle and skin were collected from Clarias gariepinus, during four surveys (February, May, June and November) in 1994 from two sites on the Olifants River in the Kruger National Park. With the use of atomic absorption spectrophotometry, metal concentrations of manganese, nickel and strontium bioaccumulated in these tissues were determined. This information was then used to differentiate between the concentrations found at the two locations and between the four survey periods. The concentration of the metals were found to be highest in the gills, followed by the liver. This suggests the gills to be the primary uptake tissue for these metals following their intimate blood-water contact. The concentration of manganese and strontium, with particular reference to the gills, showed highest bioaccumulation at Mamba. Very little differences in the nickel concentrations were found at both Mamba and Balule. Water bioconcentration factors for manganese and nickel were much higher than that noted for sediment, suggesting a much lower bioavailability of these metals from the sediment. On the other hand, sediment bioconcentration factors for strontium were generally higher than that for water, which could imply higher bioavailability and concentration from the sediment.
\end{abstract}

Keywords: manganese, nickel, strontium, Clarias gariepinus, Olifants River, Kruger National Park, gill, liver, muscle, skin.

Annemarié Avenant-Oldewage $\square$ and Hazel Marx, Department of Zoology, Rand Afrikaans University, P. 0. Box 524 Auckland Park, 2006 Republic of South Africa.

\section{Introduction}

The discharge of metal-containing waste waters has many noticeable impacts on aquatic systems. Consequently, there is a rise in residue levels in water, sediment and biota, decreasing productivity and increasing the exposure of humans to harmful substances (Moore \& Ramamoorthy 1984). When the concentration of a metal in the external media (water and food) exceeds tolerable levels, it becomes toxic to the fish (Wicklund 1991). Determining the dose of metals to which aquatic environments are exposed is not yet possible but concentrations of metals in sediments, water and, in particular, biological tissues can be employed as indicators of exposure (Nagel 1991). Studies of this nature, carried out during the 1990-1991 period on the Olifants River, were conducted on C. gariepinus by Van der Merwe (1992) and Du Preez et al. (1997) and on Barbus marequensis by Seymore et al. (1994, 1995). Data collected during the present study were compared with these results to establish any trends of the pollutants in the area. Results from the present study on the bioaccumulation of lead and, zinc and copper have been published by Marx \& Avenant-Oldewage (1998) and Kotzè et al. (1999), respectively.

Manganese is an essential micronutrient and is presumed to be homeostatically controlled (Cross et al. 1973; Giesy \& Weiner 1977). It was also shown to stimulate chondroitin sulphate synthesis, which is an important constituent of cartilage and connective tissue (Friberg et al. 1986). 


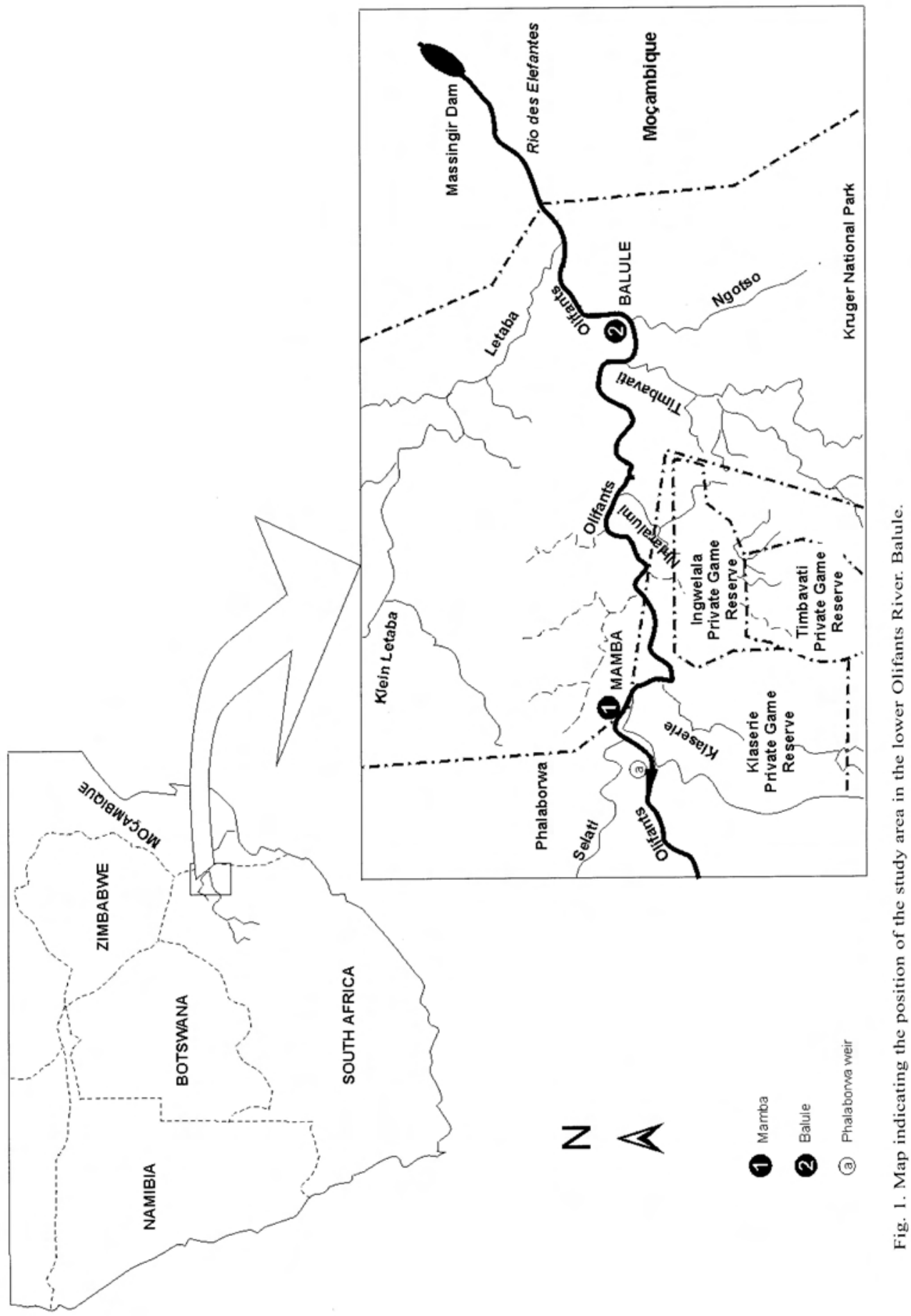


Manganese has been found to accumulate in various tissues of different animals. Studies done by Khalaf et al. (1985) revealed fairly high manganese concentrations in the gills, skin, kidney, gonads, muscle and liver from Barbus grypus. Muscle samples from a variety of fish from South Carolina-silver snapper: $0.02 \mathrm{ppm}$; mudfish: $0.03 \mathrm{ppm}$; white bass: $0.12 \mathrm{ppm}$; and catfish: $0.09 \mathrm{ppm}$ -also showed traces of manganese (Koli et al. 1978).

Nickel is physiologically important to organisms as a micronutrient, but at excessive quantities exhibits toxic effects. It has been found to have a central function in metabolism (Moore \& Ramamoorthy 1984) and inhibits a number of enzymes including cytochrome oxidase, isocitrate dehydrogenase and maleic dehydrogenase, as it occurs in the citric acid cycle (Duffus 1980; Dallas \& Day 1993). It is bound to various proteins, including metallothioneins and albumin (Dallas \& Day 1993). Nickel also plays an important role in the efficiency of iron absorption and thus blood formation (Moore \& Ramamoorthy 1984).

Strontium is potentially dangerous because it can accumulate in bones. It has a relatively long half-life ( 28 years), and the beta particles and gamma rays which it emits, destroys animal tissue (Faure \& Powell 1972; Carraça et al. 1990). Strontium has the same valence $\left(\mathrm{Sr}^{2+}\right)$ as calcium $\left(\mathrm{Ca}^{2+}\right)$ and similar ionic radii $(\mathrm{Ca}=0.99, \mathrm{Sr}=1.13)($ Radtke 1989$)$. Therefore, strontium behaves similarly to calcium (an essential element) in aquatic organisms and thus is a bone-seeking radionuclide (Becker 1990).

The Phalaborwa region has, over a number of years, lent itself to extensive mining, agricultural and urbanisation activities which has largely contributed to the deterioration of water quality within the Kruger National Park. The present study was undertaken to acquire information about the heavy metal content of natural fish populations of $C$. gariepinus from two different study sites along the Olifants River in the Kruger National Park. The focus will be on the con- centration of manganese, nickel and strontium in the tissues of $C$. gariepinus and how certain physical, chemical and biological influences affect these concentration levels. Spatial, as well as temporal differences in metal accumulation will also be investigated.

\section{Study area}

The two study sites are situated in the lower catchment area of the Olifants River (Fig. 1). The first site named Mamba is situated on the western border of the Kruger National Park in close proximity to the mining city of Phalaborwa. The second site Balule, is situated approximately $40 \mathrm{~km}$ eastwards into the interior of the park.

\section{Methods}

Four surveys were conducted at Mamba and Balule during 1994 (February, May, July and November). Samples of water and sediment were taken for metal analysis and for determining various physical and chemical parameters.

Information on the physical and chemical water parameters, as well as water and sediment metal concentrations used during this study is housed at the Department of Water Affairs and Forestry under the Historical Information System (HIS) and summarised by Marx and Avenant-Oldewage 1998.

A maximum of 20 C. gariepinus (Burchell, 1822) (sharptoothed catfish) were collected at each location for each survey. They were caught using hand lines and gill nets with mesh sizes ranging between $70-120 \mathrm{~mm}$, stretched.

The fish were killed by cutting through the spinal cord behind the head and subsequently dissected. The gills, liver, muscle and skin were dissected out and placed in separate, pre-cleaned, labelled, $25 \mathrm{ml}$ glass bottles and frozen until further analysis.

A $5 \mathrm{~g}$ sample of the pre-thawed tissue (gills, liver, muscle and skin) were weighed out into $250 \mathrm{ml}$ Erlyn Myer flasks using a Mettler PK 4800 balance. This corresponds to approximately $1 \mathrm{~g}$ dry weight. The gill filaments were removed from the gill arches and only the gill filaments were weighed. The weighed samples were dried at $60^{\circ} \mathrm{C}$ in a Haraeus Hanau KB 500 oven for 48 hours. The dried samples were re-weighed and compared to the wet sample masses to determine the percentage moisture content of the individual samples. Dried samples were 
digested according to the methods described by Van Loon (1980) and Du Preez \& Steyn (1992). A mixture of $10 \mathrm{ml}$ of $55 \%$ nitric acid $\left(\mathrm{NHO}_{3}\right)$, and $5 \mathrm{ml}$ of $70 \%$ perchloric acid $\left(\mathrm{HClO}_{4}\right)$ was added to the Erlyn Myer flasks. The samples were placed on a hot plate at $\pm 200{ }^{\circ} \mathrm{C}$ and allowed to digest until clear. The digested samples were removed to cool down and diluted to $50 \mathrm{ml}$ with distilled water. These samples were then filtered individually through a $6 \mu \mathrm{m}$ Millipore acid-resistant membrane filter attached to a vacuum pump. Between each sample the filter system was rinsed in distilled water. The samples were then carefully poured into $100 \mathrm{ml}$, acid-washed glass bottles.

Concentrations of manganese (Mn), nickel (Ni) and strontium $(\mathrm{Sr})$ were determined with the aid of a Varian Atomic Absorption Spectrophotometer (SPECTRA AA-10). Calibration of the spectrophotometer for each metal was ensured with the preparation of four to five analytical standards using Holpro stock solutions.

The bioconcentration factor between mean metal concentration found in the fish tissues and organs and the metal concentrations found in the sediment or water was determined. The calculation to determine the bioconcentration factor as proposed by Veith et al. (1979) and Wiener \& Giesy (1979).

Bioconcentration factor $\left(B c F_{\text {water }}\right)\left(B c F_{\text {sediment }}\right)=$

Metal concentration $(\mu \mathrm{g} / \mathrm{g})$ in tissue (dry weight)

Metal concentration in sediment $(\mu \mathrm{g} / \mathrm{g})$ water $(\mu \mathrm{g} / \mathrm{ml})$

This data was statistically analysed with the aid of the Statsgraphics 7 computer software. The variables determined included the mean, standard error, coefficient of variation and the minimum and maximum values (Table 1). Thereafter, SPSS 7,5 computer software was employed, whereby a MANOVA and ANOVA test was carried out to determine differences between tissue types and seasons. A $t$-test (univariate analysis) was carried out to determine the differences between the two locations (Tables 2, 3 \& 4).

\section{Results}

\section{Manganese}

Bioaccumulation of manganese (Table 1)

At both locations the gills consistently showed the highest concentration of manganese during the surveys. The concentration of manganese found in the individual fish varied. The largest variation occurred in the gills, for example during survey three at
Mamba, the concentration ranged from $38.5 \mu \mathrm{g} / \mathrm{g}$ to $102.0 \mu \mathrm{g} / \mathrm{g}$.

Bioconcentration factors of tissues and water/sediment (Table 1)

Variations for the calculated bioconcentration factors of the water $\left(\mathrm{BcF}_{\mathrm{w}}\right)$ and sediment $\left(\mathrm{BcF}_{\mathrm{s}}\right)$ became apparent from the second survey onwards. The bioconcentration factor for water was much higher, in some cases 100 times that of the sediment. The $\mathrm{BcF}_{\mathrm{w}}$ and $\mathrm{BcF}_{\mathrm{s}}$ values of the gills were persistently the highest, and that of the liver second highest. No notable difference was evident between the bioconcentration factors at Mamba and Balule, with regard to the liver and skin values, while the bioconcentration factors of the gills and skin were significantly higher at Mamba. An exception to this was seen during survey four (November 1994), where, in particular the $\mathrm{BcF}_{\mathrm{w}}$ values for all the tissues, were much higher at Balule. The $\mathrm{BcF}_{\mathrm{w}}$ values varied from 0.0 for the muscle at Mamba and Balule and the skin at Mamba (survey one) to 69.7 for the gills at Mamba (survey three). The $\mathrm{BcF}_{\mathrm{s}}$ values varied from 0.0 for the muscle at Balule during survey three to 0.1 for the gills at Mamba during survey four.

Concentration differences between the two localities

All the mean concentrations of metals in the organs and tissues were far lower at Mamba than at Balule for survey one. The liver exhibited a lower concentration at Mamba for survey two, whilst higher concentrations were recorded for the gills, muscle and skin at Mamba. The mean concentration of manganese in the gills, liver and muscle at Mamba during survey three was higher than that found at Balule during the same period, but the concentration in skin was only slightly lower at Mamba than at Balule. For survey four, the concentration in the liver, muscle and skin was only slightly lower at Mamba than what was observed at Balule.

Seasonal variation (comparison between the different surveys)

Seasonal variation was, evident, the concentration in the gills at Mamba showed an 
increase in concentration from survey late summer to early summer. At Balule, the concentrations for each survey were generally constant, with little variation occurring between the seasons. The mean metal concentration in the liver at Mamba fluctuated with no seasonal trends. The mean concentration at Balule decreased from the first (late summer) to the third survey (winter), whereafter an increase was recorded during survey four (early summer). A similar trend was found for the mean concentration of manganese in the muscle at Balule. However, the corresponding values for muscle at Mamba showed variation and, therefore, no seasonal trend. At Mamba, the mean concentration of metal in the skin was lower for survey two (autumn) when compared to survey one (late summer), whereafter, for the remainder of the year, the concentrations between the seasons were found to be constant. The mean concentration of manganese in the skin at Balule dropped to its lowest point during survey two (autumn) and was higher for the subsequent two surveys.

\section{Nickel}

\section{Bioaccumulation of nickel (Table 1)}

Generally, the site for the highest bioaccumulation of nickel was the gills, the exception being survey one at Mamba, where the liver showed a high mean concentration of $58.7 \pm 21.4 \mu \mathrm{g} / \mathrm{g}$.

Variation in the concentration of nickel in the individual tissues sampled, was high. An example of this is the concentrations in the gills found during survey three at Mamba, where the minimum and maximum concentrations were $13.3 \mu \mathrm{g} / \mathrm{g}$ and $91.2 \mu \mathrm{g} / \mathrm{g}$ respectively.

Bioconcentration factors in water and sediment (Table 1)

There was a marked variation between the bioconcentration factors of the water $\left(\mathrm{BcF}_{\mathrm{w}}\right)$ and sediment $\mathrm{BcF}_{\mathrm{s}}$ for all surveys except for survey three, where only slight variation was evident. Generally, the highest differences between the water and sediment bioconcentration factors were observed in the gills, which also displayed the highest mean concentration of nickel. The bioconcentration factors for both water and sediment for the liver, muscle and skin did not differ much from each other. The $\mathrm{BcF}_{\mathrm{w}}$ and $\mathrm{BcF}_{\mathrm{s}}$ values at both Mamba and Balule were very similar, with neither location having consistently higher bioconcentration values for any organ or tissue. The $\mathrm{BcF}_{\mathrm{w}}$ variation was between 0.5 for the muscle at Mamba during survey three and 3.6 for the gills at Balule during survey one. The variation for the $\mathrm{BcF}_{\mathrm{s}}$ values was between 0.0 for the muscle at Mamba during survey three and 0.5 for the liver, at Mamba during survey one.

Concentration differences between the two localities

The results for survey one show that the mean concentration of nickel in the gills, liver, muscle and skin is all slightly lower at Mamba compared to that of Balule. During survey two the concentrations in the liver, muscle and skin, with the exception of the gills, were higher at Mamba. During survey three the nickel concentration in the skin was lowest when compared to the concentrations in all the organs and tissues at both locations.

Seasonal variation (comparison between the different surveys)

During the study period each of the tissues showed similar seasonal patterns at both Mamba and Balule. For all surveys the mean concentration in the gills at Balule and the liver, skin and muscle from both locations, showed the same seasonal pattern. The highest concentration almost always occurred during survey one with the lowest concentration observed during survey three increasing in concentration during survey four. The concentration of nickel in the gills at Mamba showed no seasonal pattern.

\section{Strontium}

\section{Bioaccumulation of strontium (Table 1)}

During the study period undertaken it was observed that the tissue which constantly showed the highest concentrations of strontium, during all surveys, was the gills. The 
Table 1

Manganese, nickel and strontium concentrations ( $\mu \mathrm{g} / \mathrm{g}$ dry mass) in gills, liver, muscle and skin of Clarias gariepinus from the Olifants River; Kruger National Park

Survey 1, February 1994

$$
\begin{aligned}
& \text { Mamba (Locality One) } \\
& (n=20)
\end{aligned}
$$

Metal

tion $(\mu \mathrm{g} / \mathrm{g}) \quad$ Gills

$\mathrm{Mn}(\mu \mathrm{g} / \mathrm{g})$

Mean \pm SD

Min/Max

SE

CV

$\mathrm{BcFw}$

BcFs

$\mathrm{Ni}(\mu \mathrm{g} / \mathrm{g})$

Mean \pm SD

Min/Max

SE

CV

$\mathrm{BcF}_{W}$

$\mathrm{BcF}_{\mathrm{s}}$

$$
37.9 \pm 12.8
$$

(8.2-66.6)

$$
2.9
$$

33.8

0.6

0.1

Tissue types

$\operatorname{Sr}(\mu \mathrm{g} / \mathrm{g})$

Mean $\pm \mathrm{SD}$

Min/Max

SE

$\mathrm{CV}$

$\mathrm{BcF}_{\mathrm{w}}$

$\mathrm{BcF}_{\mathrm{S}}$

\section{$38.6 \pm 13.3$}

(10.4-67.1)

3.0

34.4

2.2

0.36

4.8

36.4

3.3

0.54

$227.1 \pm 74.3 \quad 5.2 \pm 4.1$

(84.6-367.6) (0.1-11.3)

16.6

0.9

78.9

0.0

0.0

0.7 concentra-

$58.7 \pm 21.4 \quad 50.9 \pm 22.0 \quad 52.3 \pm 32.0$

$(39.7-08.9) \quad(18.2-123.1) \quad(7.2-26.1)$

\begin{tabular}{|c|c|c|c|c|c|}
\hline $\begin{array}{l}0.04 \pm 0.01 \\
(0.0-0.1)\end{array}$ & $\begin{array}{l}20.5 \pm 11.1 \\
(9.2-46.5)\end{array}$ & $\begin{array}{l}217.3 \pm 64.8 \\
(125.8-391.7)\end{array}$ & $\begin{array}{l}7.6 \pm 2.3 \\
(4.7-12.7)\end{array}$ & $\begin{array}{l}2.2 \pm 0.8 \\
(1.2-4.3)\end{array}$ & $\begin{array}{l}5.8 \pm 4.3 \\
(0.3-14.6)\end{array}$ \\
\hline \multicolumn{6}{|c|}{0.02 .514 .50 .50 .21 .0} \\
\hline 15.6 & 54.2 & 29.8 & 29.6 & 38.7 & 74.1 \\
\hline 0.0 & 0.2 & 1.3 & 0.1 & 0.0 & 0.0 \\
\hline 0.0 & 0.1 & 1.3 & 0.1 & 0.0 & 0.0 \\
\hline
\end{tabular}

\begin{abstract}
0.0
\end{abstract}
Survey 2, May 1994

$$
(n=18)
$$

Balule (Locality Two) $(n=20)$

Tissue Types

$\begin{array}{llll}\text { Gills } & \text { Liver } & \text { Muscle } & \text { Skin } \\ & & & \\ 48.6 \pm 15.4 & 17.1 \pm 3.6 & 12.9 \pm 4.9 & 15.0 \pm 4.7 \\ (29.5-88.1) & (12.1-26.0) & (7.6-26.3) & (8.8-30.8) \\ 3.4 & 0.8 & 1.1 & 1.1 \\ 31.7 & 21.0 & 38.0 & 31.6 \\ 0.1 & 0.0 & 0.0 & 0.0 \\ 0.1 & 0.0 & 0.0 & 0.0\end{array}$

$4.9 \quad 7.2$

$\begin{array}{ll}4.9 & 7.2 \\ 43.3 & 61.2\end{array}$

$2.8 \quad 2.9$

$\begin{array}{ll}2.8 & 2.9 \\ 0.47 & 0.48\end{array}$

\section{$67.8 \pm 22.7$}

(43.3-134.8)

$63.5 \pm 12.8$

$52.6 \pm 18.3 \quad 55.1 \pm 16.7$

\begin{tabular}{|c|c|c|c|c|c|c|c|c|}
\hline & & $(n=18)$ & & & & $(n=20)$ & & \\
\hline $\mathrm{Mn}(\mu \mathrm{g} / \mathrm{g})$ & & & & & & & & \\
\hline Mean \pm SD & $54.3 \pm 20.2$ & $5.3 \pm 2.1$ & $10.2 \pm 8.4$ & $4.4 \pm 1.6$ & $49.8 \pm 25.6$ & $11.2 \pm 5.6$ & $3.9 \pm 1.1$ & $4.2 \pm 2.0$ \\
\hline $\operatorname{Min} / \operatorname{Max}$ & $(26.9-102.5)$ & $(1.9-10.3)$ & $(4.6-40.4)$ & $(1.9-8.0)$ & $(19.9-102.5)$ & $(6.0-25.3)$ & $(2.3-25.3)$ & $(2.2-9.8)$ \\
\hline $\mathrm{SE}$ & 4.8 & 0.7 & 2.0 & 0.4 & 5.7 & 1.3 & 0.3 & 0.4 \\
\hline $\mathrm{CV}$ & 37.3 & 54.8 & 82.0 & 36.7 & 51.5 & 50.0 & 28.7 & 47.1 \\
\hline $\mathrm{BcFw}$ & 54.3 & 5.3 & 10.2 & 4.4 & 49.8 & 11.1 & 3.9 & 4.2 \\
\hline $\mathrm{BcFs}$ & 0.0 & 0.0 & 0.0 & 0.0 & 0.0 & 0.0 & 0.0 & 0.0 \\
\hline $\mathrm{Ni}(\mu \mathrm{g} / \mathrm{g})$ & & & & & & & & \\
\hline Mean \pm SD & $38.7 \pm 23.2$ & $22.0 \pm 16.9$ & $19.7 \pm 11.4$ & $14.5 \pm 9.6$ & $52.7 \pm 31.8$ & $17.8 \pm 10.2$ & $10.6 \pm 2.7$ & $11.7 \pm 5.2$ \\
\hline $\operatorname{Min} / \operatorname{Max}$ & $(14.3-78.1)$ & $(3.7-50.0)$ & $(6.1-44.3)$ & $(5.3-36.0)$ & $(18.6-113.1)$ & $(7.6-38.8)$ & $(6.7-15.1)$ & $(7.1-26.2)$ \\
\hline SE & 5.5 & 4.0 & 2.7 & 2.3 & 7.1 & 2.3 & 0.6 & 1.2 \\
\hline $\mathrm{CV}$ & 59.9 & 77.0 & 58.0 & 66.2 & 60.4 & 57.2 & 25.2 & 43.9 \\
\hline $\mathrm{BcF}_{\mathrm{w}}$ & 9.7 & 5.5 & 4.9 & 3.5 & 13.2 & 4.5 & 2.6 & 2.9 \\
\hline $\mathrm{BcF}_{\mathrm{s}}$ & 0.4 & 0.2 & 0.2 & 0.2 & 0.4 & 0.1 & 0.1 & 0.1 \\
\hline $\mathrm{Sr}(\mu \mathrm{g} / \mathrm{g})$ & & & & & & & & \\
\hline Mean \pm SD & $367.7 \pm 122.6$ & $11.3 \pm 6.5$ & $10.0 \pm 8.2$ & $12.7 \pm 4.0$ & $196.9 \pm 104.3$ & & & $30.3 \pm 7.7$ \\
\hline $\operatorname{Min} / \operatorname{Max}$ & $(145.7-692.0)$ & $(4.7-26.7)$ & $(3.2-39.6)$ & $(5.4-19.1)$ & $(27.5-395.4)$ & & & $(21.4-56.7)$ \\
\hline SE & 28.9 & 1.5 & 1.9 & 0.9 & 23.3 & N/A & N/A & 1.7 \\
\hline $\mathrm{CV}$ & 33.3 & 57.8 & 82.4 & 31.1 & 53.0 & & & 25.6 \\
\hline $\mathrm{BcF}_{\mathrm{w}}$ & 0.4 & 0.0 & 0.0 & 0.0 & 0.2 & & & 0.0 \\
\hline $\mathrm{BcF}_{\mathrm{S}}$ & 0.4 & 0.0 & 0.0 & 0.0 & 0.3 & & & 0.0 \\
\hline
\end{tabular}

$(25.7-106.6) \quad(37.0-110.0)$

$\begin{array}{llll}5.1 & 2.9 & 4.1 & 3.7\end{array}$

$\begin{array}{llll}33.5 & 20.2 & 34.8 & 30.4\end{array}$

$\begin{array}{lllll}.9 & 3.6 & 3.3 & 2.8 & 2.9 \\ .48 & 0.44 & 0.41 & 0.40 & 0.40\end{array}$


Table 1 (continued)

Survey 3 , July 1994

$(n=20) \quad(n=20)$

\begin{tabular}{|c|c|c|c|c|c|c|c|c|}
\hline \multicolumn{9}{|l|}{$\mathrm{Mn}(\mu \mathrm{g} / \mathrm{g})$} \\
\hline Mean \pm SD & $69.7 \pm 14.0$ & $10.8 \pm 6.5$ & $3.1 \pm 2.0$ & $4.5 \pm 2.3$ & $46.5 \pm 17.2$ & $7.1 \pm 2.5$ & $2.3 \pm 0.3$ & $5.1 \pm 1.2$ \\
\hline $\mathrm{Min} / \mathrm{Max}$ & $(38.5-102.0)$ & $(4.1-29.4)$ & $(1.3-9.0)$ & $(2.4-11.2)$ & $(18.5-86.2)$ & $(3.4-13.2)$ & $(1.9-3.2)$ & $(3.9-8.1)$ \\
\hline SE: & 3.2 & 1.5 & 0.4 & 0.5 & 3.9 & 0.6 & 0.1 & 0.3 \\
\hline CV & 20.0 & 60.0 & 63.8 & 51.7 & 37.2 & 35.0 & 12.9 & 23.5 \\
\hline $\mathrm{BcF}_{\mathrm{w}}$ & 69.7 & 10.8 & 3.1 & 4.5 & 46.5 & 7.1 & 2.3 & 5.1 \\
\hline $\mathrm{BcF}_{\mathrm{s}}$ & 0.1 & 0.0 & 0.0 & 0.0 & 0.0 & 0.0 & 0.0 & 0.0 \\
\hline \multicolumn{9}{|l|}{$\mathrm{Ni}(\mu \mathrm{g} / \mathrm{g})$} \\
\hline Mean \pm SD & $37.8 \pm 19.2$ & $17.4 \pm 9.6$ & $8.7 \pm 0.8$ & $9.6 \pm 2.4$ & $28.4 \pm 15.6$ & $11.7 \pm 6.0$ & $8.0 \pm 0.5$ & $10.5 \pm 3.6$ \\
\hline $\operatorname{Min} / \operatorname{Max}$ & $(13.3-91.2)$ & $(6.7-35.4)$ & $(7.0-10.0)$ & $(7.5-15.3)$ & $(11.2-68.4)$ & $(6.2-25.8)$ & $(6.9-8.6)$ & $(6.2-16.0)$ \\
\hline SI: & 4.4 & 2.2 & 0.2 & 0.5 & 3.5 & 1.3 & 0.1 & 0.8 \\
\hline $\mathrm{CV}$ & 50.8 & 55.3 & 8.6 & 25.5 & 55.0 & 51.0 & 6.1 & 33.9 \\
\hline $\mathrm{BcF}_{\mathrm{w}}$ & 2.1 & 1.0 & 0.5 & 0.5 & 1.9 & 0.8 & 0.5 & 0.7 \\
\hline $\mathrm{BcF}_{\mathrm{s}}$ & 0.2 & 0.1 & 0.0 & 0.0 & 0.2 & 0.1 & 0.1 & 0.1 \\
\hline \multicolumn{9}{|l|}{$\operatorname{Sr}(\mu \mathrm{g} / \mathrm{g})$} \\
\hline Mean \pm SD & $386.2 \pm 148.0$ & $13.1 \pm 7.4$ & $7.8 \pm 3.0$ & - & $300.4 \pm 81.8$ & $7.6 \pm 3.0$ & $4.9 \pm 1.2$ & $13.9 \pm 5.9$ \\
\hline $\operatorname{Min} / \mathrm{Max}$ & $(154.4-830.3)$ & $(6.9-29.0)$ & $(4.9-15.5)$ & & $(174.4-441.1)$ & $(3.4-13.6)$ & $(1.9-7.5)$ & $(6.9-27.4)$ \\
\hline SI: & 33.9 & 1.7 & 0.7 & N/A & 18.3 & 0.7 & 0.3 & 1.3 \\
\hline $\mathrm{CV}$ & 38.3 & 56.4 & 39.2 & & 27.2 & 40.1 & 25.1 & 42.3 \\
\hline $\mathrm{BcF}_{w}$ & 0.1 & 0.0 & 0.0 & & 0.1 & 0.0 & 0.0 & 0.0 \\
\hline $\mathrm{BcF}_{\mathrm{s}}$ & 4.6 & 0.2 & 0.1 & & 0.5 & 0.0 & 0.0 & 0.0 \\
\hline
\end{tabular}

Survey 4, November 1994

\begin{tabular}{|c|c|c|c|c|c|c|c|c|}
\hline & & $(n=19)$ & & & & $(n=20)$ & & \\
\hline $\operatorname{Mn}(\mu \mathrm{g} / \mathrm{g})$ & & & & & & & & \\
\hline Mean \pm SD & $74.5 \pm 22.1$ & $9.9 \pm 3.8$ & $4.4 \pm 1.2$ & $4.5 \pm 2.0$ & $45.0 \pm 9.3$ & $10.3 \pm 4.3$ & $5.0 \pm 2.2$ & $5.2 \pm 2.3$ \\
\hline $\operatorname{Min} / \operatorname{Max}$ & $(40.6-126.1)$ & $(5.5-21.6)$ & $(3.1-7.2)$ & $(1.9-8.1)$ & $(30.3-63.0)$ & $(3.4-20.2)$ & $(2.5-10.1)$ & $(2.7-11.1)$ \\
\hline SE & 5.1 & 0.9 & 0.3 & 0.5 & 2.1 & 1.0 & 0.5 & 0.5 \\
\hline $\mathrm{CV}$ & 29.6 & 37.9 & 26.8 & 44.8 & 20.7 & 42.5 & 43.5 & 44.5 \\
\hline $\mathrm{BcF}_{\mathrm{w}}$ & 8.3 & 1.1 & 0.5 & 0.5 & 45.0 & 10.3 & 5.0 & 5.2 \\
\hline $\mathrm{BcF}_{\mathrm{s}}$ & 0.1 & 0.0 & 0.0 & 0.0 & 0.1 & 0.0 & 0.0 & 0.0 \\
\hline $\mathrm{Ni}(\mu \mathrm{g} / \mathrm{g})$ & & & & & & & & \\
\hline Mean \pm SD & $39.3 \pm 14.5$ & $22.5 \pm 7.7$ & $15.3 \pm 2.9$ & $16.0 \pm 4.0$ & $33.0 \pm 11.1$ & $17.4 \pm 4.7$ & $20.9 \pm 2.9$ & $15.2 \pm 3.9$ \\
\hline $\operatorname{Min} / \operatorname{Max}$ & $(16.2-75.4)$ & $(13.1-40.4)$ & $(11.9-20.9)$ & $(11.8-24.3)$ & $(19.9-65.0)$ & $(11.7-26.2)$ & $(18.2-25.2)$ & $(9.7-23.2)$ \\
\hline SE: & 3.3 & 1.8 & 0.7 & 0.9 & 2.5 & 1.0 & 0.7 & 0.9 \\
\hline $\mathrm{CV}$ & 36.9 & 34.3 & 19.2 & 25.0 & 33.6 & 26.7 & 13.8 & 25.6 \\
\hline $\mathrm{BcF}_{\mathrm{w}}$ & 9.8 & 5.6 & 3.8 & 4.0 & 8.2 & 4.3 & 5.2 & 3.8 \\
\hline $\mathrm{BcF}_{\mathrm{s}}$ & 0.3 & 0.1 & 0.1 & 0.1 & 0.3 & 0.2 & 0.2 & 0.1 \\
\hline $\mathrm{Sr}(\mu \mathrm{g} / \mathrm{g})$ & & & & & & & & \\
\hline Mean \pm SD & $533.3 \pm 122.7$ & $35.4 \pm 12.9$ & $17.5 \pm 2.7$ & $22.3 \pm 5.8$ & $247.7 \pm 51.5$ & $13.9 \pm 6.9$ & $8.2 \pm 1.4$ & $12.9 \pm 2.5$ \\
\hline $\operatorname{Min} / \operatorname{Max}$ & $(344.0-785.7)$ & $(20.5-65.2)$ & $(13.0-24.0)$ & $(12.7-37.9)$ & $(171.2-391.2)$ & $(4.3-27.6)$ & $(6.1-11.5)$ & $(7.5-17.0)$ \\
\hline SE & 28.2 & 3.0 & 0.6 & 1.3 & 11.5 & 1.6 & 0.3 & 0.6 \\
\hline $\mathrm{CV}$ & 23.0 & 36.3 & 15.2 & 25.8 & 20.8 & 49.9 & 16.8 & 19.6 \\
\hline $\mathrm{BcF}_{\mathrm{w}}$ & 0.2 & 0.0 & 0.0 & 0.0 & 0.2 & 0.0 & 0.0 & 0.0 \\
\hline $\mathrm{BcF}_{\mathrm{s}}$ & 1.8 & 0.1 & 0.0 & 0.0 & 1.1 & 0.1 & 0.0 & 0.1 \\
\hline
\end{tabular}

$\mathrm{Mn}(\mu \mathrm{g} / \mathrm{g})=$ manganese concentration; $\mathrm{Ni}(\mu \mathrm{g} / \mathrm{g})=$ nickel concentration; $\mathrm{Sr}(\mu \mathrm{g} / \mathrm{g})=$ strontium concentration; $\mathrm{SE}=$ standard error; $\mathrm{CV}=$ coefficient of variation; $\mathrm{N} / \mathrm{A}=$ not available

Bioconcentration factor $\left(\mathrm{BcF}_{\text {water }}\right)\left(\mathrm{BcF}_{\text {sediment }}\right)=$ Metal concentration $(\mu \mathrm{g} / \mathrm{g})$ in tissue (dry weight)

Metal concentration in sediment $(\mu \mathrm{g} / \mathrm{g})$ water $(\mu \mathrm{g} / \overline{\mathrm{ml}})$ 
Table 2

Significance levels for tissue types versus seasons. The significance values above 0.000 are highlighted in bold or bold and italics. This table should be used in conjunction with Tables 3 and 4

$\begin{array}{lcc}\text { Legend } & \begin{array}{c}\text { Tissue Type } \\ \text { Significance values }\end{array} & \begin{array}{c}\text { Seasons } \\ \text { Significance }\end{array} \\ & & \\ \text { Manganese (Mn) } & 0.000 & - \\ \text { Nickel (Ni) } & 0.000 & 0.000 / \mathbf{0 . 0 0 4} \\ \text { Strontium (Sr) } & 0.000 / \mathbf{0 . 0 0 1} & 0.044 / \mathbf{0 . 0 2 0}\end{array}$

large variation in the concentrations of the different tissues for the individual fish, is noticable. For example, the variation in the concentration of strontium in the gills at Mamba during survey three, ranged from $154.4 \mu \mathrm{g} / \mathrm{g}$ to $830.3 \mu \mathrm{g} / \mathrm{g}$.

Bioconcentration factors in water and sediment (Table 1)

Small differences were noted between the two concentration factors. The sediment bioconcentration factor $\left(\mathrm{BcF}_{\mathrm{s}}\right)$ for strontium was unique when compared to all other metals examined, particularly so for the first survey. Both concentration factors $\left(\mathrm{BcF}_{\mathrm{w}}\right.$ and $\mathrm{BcF}_{\mathrm{s}}$ ) were relatively low, with few calculations exceeding one. The greatest bioconcentration factors $\left(\mathrm{BcF}_{\mathrm{w}}\right.$ and $\left.\mathrm{BcF}_{\mathrm{s}}\right)$ were calculated for the gills. The bioconcentration factors for the water and sediment and the muscle showed the lowest values. No notable difference was observed between bioconcentration factors at Mamba and Balule.

Concentration differences between the two localities

The general trend, especially observed in the latter stages of the 1994 study period, pointed to Mamba as having the highest concentration of strontium in all the tissues analysed. The findings for survey one and two were, however, conflicting. Comparing data, it was found that for survey one, the mean concentrations found in the gills and the skin were higher at Mamba, whilst the liver and muscle concentrations were lower. In survey two, the results from only two tissues could be compared and it was noted that the mean concentration in the gills was almost twice as high as the concentration at Balule, while the concentration in the skin was half the concentration found at Balule. Both the third and fourth surveys showed all-round higher concentrations at Mamba.

Table 3

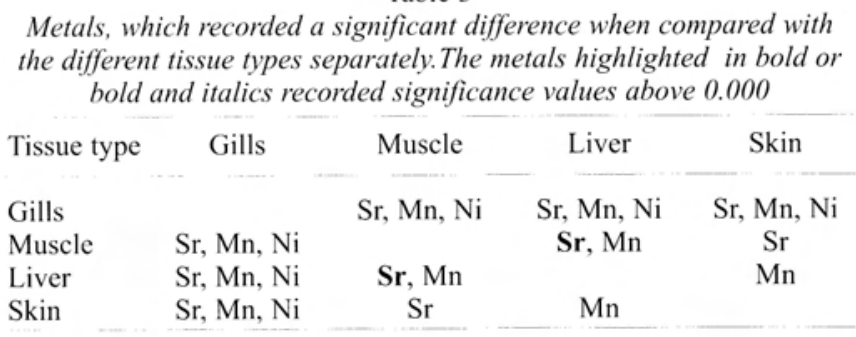


Table 4

Metals, which recorded a significant difference when compared with the different seasons separately. The metals highlighted in bold or bold and italics recorded significance values above 0.000

\begin{tabular}{lcccc}
\hline Seasons & Summer & Autumn & Winter & Spring \\
\hline Summer & & $\mathrm{Sr}, \mathrm{Ni}$ & $\mathrm{Ni}$ & $\boldsymbol{S r}, \mathrm{Ni}$ \\
Autumn & $\mathrm{Sr}, \mathrm{Ni}$ & $\mathrm{Ni}$ & $\mathrm{Ni}$ & \\
Winter & $\mathrm{Ni}$ & $\mathrm{Ni}$ & $\mathrm{Ni}$ & $\mathrm{Ni}$ \\
Spring & $\boldsymbol{S r}, \mathrm{Ni}$ & & $\mathrm{Ni}$ & \\
\hline
\end{tabular}

Seasonal variation (comparison between the different surveys)

Seasonal variation was evident between the different tissues and different locations. The mean concentration for the gills and liver at Mamba, during 1994, showed an increase in each survey from the first to the fourth survey. The results at Mamba showed a low during autumn and an increase in the surveys carried out during winter and early summer. At Balule, the concentration peaked during autumn and then subsequently decreased in winter and early summer.

\section{MANOVA (Tables 2-4)}

Tissue types

A value of 0.000 was recorded as significance value when the Wilks Lambda test was employed for tissue types. This indicates an absolute significant difference between tissue types with a $99 \%$ confidence limit.

\section{Seasons}

A value of 0.000 was recorded as significance value when the Wilks Lambda test was employed for seasons. This indicates an absolute significant difference between seasons with a $99 \%$ confidence limit.

\section{Locations}

A value of 0.000 was recorded as significance value when the Hotelling $T^{2}$ test was employed for locations. This indicates an absolute significant difference between locations with a $99 \%$ confidence limit.

\section{ANOVA}

Tissue types

Univariate analysis of variance was introduced to determine the metal types most significant or suggestive of differences between the fish tissue types.

A significant difference was recorded when gills were compared to muscle, liver and skin for all three metals, with a significance value of 0.000 being recorded for all three. A significant difference for two metals were recorded when muscle was compared to liver, namely for, manganese and strontium, with a significance value slightly above 0.000 being recorded for strontium at 0.001 . A significant difference was recorded for only one metal when the muscle and skin were compared with each other, namely for strontium, with a significance value of 0.000 . Like wise, a significant difference was recorded for only one metal, namely manganese when the liver and skin were compared, also with an absolute significance value of 0.000 .

\section{Seasons}

A significant difference was recorded when the February survey was compared with the May survey for only two of the three metals namely for nickel and strontium, with a significance value above 0.000 being recorded for strontium at 0.044 , a value very close to the 0.05 significance limit. Likewise a significant difference was recorded when summer was compared with the November survey for the same two metals, again a significance value above 0.000 was recorded for strontium at 0.020 . When summer was com- 
Table 4

Metals, which recorded a significant difference when compared with the different seasons separately. The metals highlighted in bold or bold and italics recorded significance values above 0.000

\begin{tabular}{lcccc}
\hline Seasons & Summer & Autumn & Winter & Spring \\
Summer & & $\mathrm{Sr}, \mathrm{Ni}$ & $\mathrm{Ni}$ & $\boldsymbol{S r}, \mathrm{Ni}$ \\
Autumn & $\mathrm{Sr}, \mathrm{Ni}$ & $\mathrm{Ni}$ & $\mathrm{Ni}$ & \\
Winter & $\mathrm{Ni}$ & $\mathbf{N i}$ & $\mathrm{Ni}$ & $\mathrm{Ni}$ \\
Spring & $\boldsymbol{S r}, \mathrm{Ni}$ & & $\mathrm{Ni}$ &
\end{tabular}

Seasonal variation (comparison between the different surveys)

Seasonal variation was evident between the different tissues and different locations. The mean concentration for the gills and liver at Mamba, during 1994, showed an increase in each survey from the first to the fourth survey. The results at Mamba showed a low during autumn and an increase in the surveys carried out during winter and early summer. At Balule, the concentration peaked during autumn and then subsequently decreased in winter and early summer.

\section{MANOVA (Tables 2-4)}

Tissue types

A value of 0.000 was recorded as significance value when the Wilks Lambda test was employed for tissue types. This indicates an absolute significant difference between tissue types with a $99 \%$ confidence limit.

\section{Seasons}

A value of 0.000 was recorded as significance value when the Wilks Lambda test was employed for seasons. This indicates an absolute significant difference between seasons with a $99 \%$ confidence limit.

\section{Locations}

A value of 0.000 was recorded as significance value when the Hotelling $T^{2}$ test was employed for locations. This indicates an absolute significant difference between locations with a $99 \%$ confidence limit.

\section{ANOVA}

Tissue types

Univariate analysis of variance was introduced to determine the metal types most significant or suggestive of differences between the fish tissue types.

A significant difference was recorded when gills were compared to muscle, liver and skin for all three metals, with a significance value of 0.000 being recorded for all three. A significant difference for two metals were recorded when muscle was compared to liver, namely for, manganese and strontium, with a significance value slightly above 0.000 being recorded for strontium at 0.001 . A significant difference was recorded for only one metal when the muscle and skin were compared with each other, namely for strontium, with a significance value of 0.000 . Like wise, a significant difference was recorded for only one metal, namely manganese when the liver and skin were compared, also with an absolute significance value of 0.000 .

\section{Seasons}

A significant difference was recorded when the February survey was compared with the May survey for only two of the three metals namely for nickel and strontium, with a significance value above 0.000 being recorded for strontium at 0.044 , a value very close to the 0.05 significance limit. Likewise a significant difference was recorded when summer was compared with the November survey for the same two metals, again a significance value above 0.000 was recorded for strontium at 0.020 . When summer was com- 
pared with the July survey, and spring was compared with winter a significant difference was only recorded for nickel with significance value of 0.000 . When winter was compared with autumn again a significant difference was only recorded for nickel, with a significance value slightly above 0.000 at 0.004 .

\section{Locations}

The $t$-test was employed to determine the significant difference between the two locations. For Manganese a value of 0.320 applies whereby equal variance was not assumed, this value is high above the 0.05 maximum limit. Likewise a significance value of 0.766 was recorded for nickel, again equal variance is not assumed. A significance value below the 0.05 maximum limit for significance was recorded for strontium, with a value of 0.002 , here a $5 \%$ significance level applies which indicates a $95 \%$ confidence limit, again equal variance was not assumed for strontium.

\section{Discussion}

The coefficient of variation (cv) which reflects variation among individual fish was relatively high. Generally, it was the result of mostly single tissue samples which contained high concentration levels. Similar large variations have been observed by other scientists in related studies (Pagenkopf \& Neumann 1974; Ray 1978; Du Preez \& Steyn 1992; Marx \& Avenant-Oldewage 1998; Avenant-Oldewage et al. in press).

Concentration differences were also observed for the individual metals in the same tissues. An important factor which must be remembered is that metal concentrations in fish are the result of complex processes associated with uptake and excretion rates and homeostasis in fish (Giesy \& Wiener 1977; Heath 1987).

Manganese accumulation varied between the different tissues. A distinctive order for bioaccumulation of manganese was noted for the entire study period, namely: gills
$>$ liver $>$ skin $\geq$ muscle. Consistent with these findings, Khalaf et al. (1985), Du Preez \& Steyn (1992) and Seymore et al. (1995), showed similar results. Bioaccumulation studies done on $C$. gariepinus by Van der Merwe (1992) and Du Preez et al. (1997) were performed on wet mass. These results are therefore not directly comparable with the present study. Avenant-Oldewage et al. (in press) provided a formula to calculate a comparable value. The accumulation of manganese in the gills was far higher than any of the other tissues. However, excluding the analyses of gut contents as used by Seymore et al. (1995), the gills proved to have the highest manganese concentrations and are the site where manganese enters the body. That the gills are the principal tissue for manganese uptake is also confirmed by Seymore et al. (1995) that showed that little resorption of the manganese occurs from the gut.

The gills are continually exposed to the external environment and the dissolved pollutants therein. Therefore, over and above ions that passively move in and out of the body via the gills (Stagg \& Shuttleworth 1982; Heath 1987), particulate matter, which could attach to the gill surface or surrounding mucous, may also contribute to the high concentrations found in the gills (Heath 1987).

The pattern of tissue bioaccumulation and the level of bioaccumulation did not differ much between the two locations, Mamba and Balule, except for the mean concentration in the gills. Results from surveys two, three and four indicate that the concentration in the gills at Mamba, showed that this location was more polluted than Balule, with the other tissues not reflecting conclusive results. The alkalinity or hardness has an effect on the amount of manganese which is bioavailable to the fish (Prosi 1979). The greater the alkalinity in the water, the less manganese is bioavailable as was observed for the water at Balule, which was much harder than at Mamba. Increased bicarbonate activity decreases manganese solubility as it forms complexes with bicarbonate and sul- 
phate. Furthermore, at high concentrations, bicarbonate has been found to reduce the oxidation rate of manganese (Wetzel 1983). Adding to this, Moreau et al. (1983) have shown that the uptake of manganese by fish is greater at lower ambient calcium concentrations.

With regard to seasonal differences, the moderate temperature fluctuations had no effect on the rate of manganese uptake by the fish, as no seasonal trend was evident. However, the much higher manganese concentrations found in the gills at Mamba during survey four can, according to Seymore et al. (1995), be due to heavy rainfall which is expected in the months leading up to November. Hahne \& Kroontjie (1973) show that under high rainfall conditions leaching is more pronounced and ecosystems usually have lower $\mathrm{pH}$ values. From these findings, Seymore et al. (1995) have deduced that more hydrogen ions will be available to compete with manganese for binding sites on particle surfaces and solution ligands. This will ultimately increase the bioavailability of manganese to fish. Even at low concentrations the increase could have been contributed to the higher accumulation in the fish during that period.

Cairns et al. (1975) have shown that temperature affects fish metabolism, with the uptake rate of metals increasing at higher temperatures (Prosi 1979). This could perhaps also explain the higher concentration of manganese in the gills at Mamba during November. The high uptake rate of manganese by the gills can also be explained by the regulation of manganese (Kwasnik et al. 1978), which, as was seen in the present study's results, prevents accumulation thereof in the remaining tissues.

Manganese concentrations in the water were relatively low for the study period during 1994 (Table 1). Studies on gut contents of a detritus feeding aquatic insect Tipula spp. accounted for $70 \%$ of the total body concentrations of manganese (Elwood et al. 1976). Elwood et al. (1976) further showed the importance of this source of contamina- tion to the trophic transfer of elements in the aquatic food chain. Benthos gut manganese concentrations are dependant on sediment concentrations, which through diet, is transferred in this case to the white sucker (Elwood et al. 1976).

Wren et al. (1983), proposed that tissue concentrations of most metals, including manganese, are influenced by the association of fish with bottom sediments rather than their position in the food chain. In their studies on metal concentrations in fish, Wiener \& Giesy (1979) found no correlation between the bioconcentration of manganese and fishes of different trophic levels. Kwasnik et al. (1978), have shown through their results that concentration factors for ${ }^{54} \mathrm{Mn}$ decrease with ascent up a food chain when uptake is solely through water.

Apart from survey one where the bioconcentration factors for both sediment and water were similar, surveys two to four showed the bioconcentration factors for the sediment $\left(\mathrm{BcF}_{\mathrm{S}}\right)$ to be much lower than that found for the water bioconcentration factors $\left(\mathrm{BcF}_{\mathrm{w}}\right)$ at both Mamba and Balule. The sediment bioconcentration factors $\left(\mathrm{BcF}_{\mathrm{s}}\right)$ were always lower than 1.00 . The bioconcentration factors between the fish tissues and the sediment were found to be low, which suggests that manganese in the sediment was only slightly bioavailable to fish for uptake. The findings of high sediment manganese concentrations with corresponding low bioavailability of this source of manganese to the fish are substantiated by the Canadian Guidelines (Environment Canada 1987) report that states that manganese is very likely to adsorb to silicate surfaces such as sand and sediment. However, the $\mathrm{BcF}_{\mathrm{s}}$ for the gills in November 1994, was two to three times higher than calculated in any of the other surveys, showing bioavailability from the sediment to be much higher during this time. The much higher $\mathrm{BcF}_{\mathrm{w}}$ determined between the tissues and water implies that the metal bioavailability to the fish through the water was much greater. From survey one it was evident that with the very low $\mathrm{BcF}_{\mathrm{w}}$ values, little of the high water man- 
ganese concentration was bioavailable for uptake. Results obtained for the $\mathrm{BcF}_{\mathrm{s}}$ and the $\mathrm{BcF}_{\mathrm{w}}$ at Mamba and Balule by Van der Merwe (1992) and Du Preez et al. (1997) for C. gariepinus and Seymore et al. (1994) for $B$. marequensis, were much higher than what was determined for this study, with $\mathrm{BcF}_{\mathrm{w}}$ values far exceeding the values found in this study.

\section{Nickel}

According to Jenkins (1980), numerous aquatic plants and animals have the capacity of bioaccumulating nickel. Certain organisms bioconcentrate nickel tissues. In the experimental fish, C. gariepinus, nickel distribution was observed in all the tissues examined with the following order namely: gills $>$ liver $>$ skin $\geq$ muscle. Similar patterns of accumulation were obtained by Tjälve et al. (1988) and Du Preez \& Steyn (1992). As one can conclude from above, it is reasonable to assume that there is primary uptake of nickel by way of the gills in which there is an intimate blood-water contact.

According to Tjälve et al. (1988) nickel appears to have an affinity for tissues participating in haemopoiesis and hence some of the blood cells produced will carry nickel ions. The high liver nickel concentrations can lead one to believe that the liver, which is a highly vascularised organ, is in continual contact with blood carrying nickel and when an excess of nickel is present in the body it would probably be stored in the liver.

When comparing results between Mamba and Balule, it was noted that the pattern and level of bioaccumulation showed no significant difference between the two locations. The toxicity of nickel to aquatic life, as well as its bioavailability to fish, has been shown to alter notably with different animal species, water hardness, $\mathrm{pH}$, salinity and the additive, synergistic and antagonistic behaviour with other metals (Duodoroff \& Katz 1953; Pickering \& Henderson 1966; Prosi 1979; Khangarot \& Ray 1990).
The water at Balule had much higher concentrations of alkalinity, than at Mamba. This increase in hardness decreases toxicity and bioavailability of the nickel to the fish.

The $\mathrm{pH}$ range, for both Mamba and Balule throughout the study period, was alkaline. The tendency for nickel ions is that at $\mathrm{pH}$ values less than 6.5 they predominate as soluble divalent cations, while at a $\mathrm{pH}$ above 6.7, nickel predominantly forms insoluble hydroxides, carbonates and oxides (Birge \& Black 1980; Sunderman \& Oskarsson 1991).

A seasonal pattern was evident, with all the tissues showing higher bioaccumulation of nickel during the warmer months (February and November 1994) and lower bioaccumulation during the colder winter month of July 1994.

Very little literature is available on bioconcentration factors of nickel in fish. Snodgrass (1980) showed that nickel at a high pH readily adsorbs to clay particles in the sediment, thereby making it impossible for this insoluble form of nickel to be bioavailable to the fish. The higher calculated $\mathrm{BcF}_{\mathrm{w}}$ values between the tissues and water, suggests that metal bioavailability to fish through water was much greater. Water and sediment bioconcentration factors obtained by Seymore et al. (1994), for B. marequensis at Mamba and Balule, were far lower than that calculated for this study. Comparisons made with Van der Merwe's (1992) study and Du Preez et al. (1997) showed lower $\mathrm{BcF}_{\mathrm{w}}$ values for the present study, while $\mathrm{BcF}_{\mathrm{s}}$ values were seen to have increased in surveys one and two.

\section{Strontium}

Information, regarding research studies on the bioaccumulation of strontium in freshwater fish, is rare. However during this study the concentration of strontium in fish was investigated and high levels were detected in the sampled fish. The degree of strontium accumulation in the tissues from the highest to lowest concentration was as follows. gills $>>$ liver $\geq$ skin $>$ muscle. Work done in the same study area, on B. marequensis (Sey- 
more et al. 1995) showed concentrations in the gills to be higher than that obtained in the present study. The remaining tissues showed great variation, being either higher or lower in concentration, when compared to this study's results.

Feeding and immersion studies performed by Schiffman (1961) indicated that the gills of the rainbow trout were a major pathway for the uptake of strontium from the water. Additionally, the gills are known to play a vital role in homeostasis by their ability to actively take up particular ions and to excrete metabolic products. From studies done during the time period 1944-1984, Becker (1990), refers to results of studies done on the elimination of ${ }^{90} \mathrm{Sr}$. It was determined that fish primarily eliminate ${ }^{90} \mathrm{Sr}$ from their gills against a concentration gradient and excretion of ${ }^{90} \mathrm{Sr}$ was via the kidney and lower intestine. Schiffman (1961), postulates that the high outflux rate of diffusable strontium is reflected in the inability of fish to concentrate high strontium levels in their tissues.

Once inside the fish, approximately half of the ionised strontium is converted to a nondiffusable form, by binding to protein in the blood. Circulating protein-bound strontium has an affinity for bone and binds as forcefully as calcium to the bone (Schiffman 1961; Phillips \& Russo 1978).

The results from both survey three and survey four conclusively show that concentrations of strontium in all the tissues were higher at Mamba than at Balule. No definite preference with regard to which site had the highest concentration of strontium, could be established for survey one and survey two.

Increasing calcium concentrations in water decreases strontium uptake by aquatic organisms due to the similarity of the two elements (Preston et al. 1967). This similarity introduces the factor of competition between calcium and strontium ions, for binding sites on gills, blood proteins and bone (Schiffman 1961). The fact that the concentration of strontium in the water for survey three and four, in particular, was much higher at Mamba and the alkalinity $\left(\mathrm{CaCO}_{3}\right)$ much lower than Balule, confirms the findings of higher accumulation for all the tissues at Mamba during these periods.

Except for survey one (February 1994), when the bioconcentration factors determined for tissues and water were higher than that found for sediment, the remaining three surveys exhibited opposite findings of higher sediment bioconcentration factors to water bioconcentration factors. The lower $\mathrm{BcF}_{\mathrm{w}}$ suggests that only a small fraction of strontium found in the water was bioavailable to the fish for uptake, while higher strontium concentrations were bioavailable from the sediment. The bioconcentration factors for both the water and sediment were highest in the gills. Bioconcentration factors $\left(\mathrm{BcF}_{\mathrm{s}}\right.$ and $\left.\mathrm{BcF}_{\mathrm{w}}\right)$ in excess of what was determined in this study, were calculated by Seymore et al. (1995) in B. marequensis.

\section{MANOVA}

The significant level of 0.000 obtained for tissue types, seasons and locations, indicates an absolute significant difference for each group when compared to all metals tested for. Any value between 0.010 and 0.000 represents a significant value, which provides a $99 \%$ confidence level to the researcher. Consequently, there is only a $1 \%$ chance that the tissue types, seasons and locations may not significantly differ from each other during comparison. Because the value obtained is 0.000 the $1 \%$ chance that the group will be misclassified in this manner is minimal. This enables any further statistical computations to be carried out on these groups with the confidence that they differ significantly from each other.

\section{ANOVA}

\section{Tissue type}

The various tissue types in combination selected for all three metals, almost exclusively recording 0.000 significance values. This suggests a $95 \%$ confidence limit of correctly predicting these metals when comparing the different tissue types with each other. 
The significant value recorded above 0.000 at 0.001 was recorded for strontium when the liver and muscle were compared, this still indicates a strong significant difference between these two tissue types. After liver detoxification or transformation of pollutants, a large quantity of these products are excreted via the gills, skin or bile, the storage of these products takes place when these excretory processes become overloaded, or when the rate of uptake of pollutants exceeds the ability of the liver to cope with the demand for detoxification, storage can then take place in the muscle. The fact that a significant difference exists between the liver and muscle suggests that the fish sampled recorded markedly different concentrations for these two tissue types, liver concentrations generally being higher than muscle concentrations. This indicates that these fish are generally coping with the stresses of exposure to these metals, as the storage of these pollutants has been limited.

\section{Seasons}

The four different seasons in combination only selected for two of the three metals, excluding manganese. This suggests that no significant difference was observed between seasons sampled for this metal. (Manganese is an essential micronutrient, presumably homeostatically controlled (Cross et al. 1973; Giesy \& Weiner 1977). Homeostasis refers to the maintenance of the constancy of internal environment of the body or part of the body; this indicates the maintenance of equilibrium between organism and environment. If this idea is applied here, one would assume that the fish during any of the four seasons sampled, would maintain the equilibrium between manganese concentrations in the surrounding environment and their internal systems. This would in turn be indicated by the fact that no significant difference was recorded between the seasons for manganese.

Only when autumn was compared with summer and then with spring were significance values recorded below the 0.05 maximum limit for strontium, with a high significance value for the autumn summer combination of 0.040. Autumn and summer concentrations may well be similar resulting in a weaker significant difference as autumn is a transition period between summer and winter, the concentrations may not have differed significantly by the following survey in autumn to provide a 0.00 significant difference. The summer and winter combination however. did not record a significance value below the 0.050 maximum significance limit, suggesting that the concentrations recorded during these two seasons were similar. A significance value of 0.020 , also high, was recorded during the spring summer combination and this possibly indicates the introduction of strontium into the river system, as a decrease in the differentiation between sea. sons was noted as the study progressed. During most of the combinations for seasons. significance values at 0.000 , i.e., below 0.050 were recorded, with the exception of the autumn winter combination where a sig. nificance value of 0.004 was recorded. It has been reported by Snodgrass (1980) and Moore \& Ramamoorthy (1984) that the mechanisms influencing the solubility of nickel include acid-base reactions and oxidation-reduction reaction. Both these are influenced by temperature (Wetzel 1983). The high significant difference recorded for seasons may well indicate temperature dependence with regards to nickel bioaccumulation in fish.

\section{Locations}

The $t$-test was employed to test the significant difference between the two locations. A significance value below 0.050 was only recorded for strontium with a significance value of 0.002 . In calcium-rich waters, calcium will compete with strontium in the uptake process, which results in lower strontium accumulation by the fish (Phillips \& Russo 1978). The $\mathrm{CaCO}_{3}$ and $\mathrm{Ca}$ concentrations recorded throughout the study were predominantly higher at the less polluted sight, i.e. Balule, which may well have resulted in the differences observed in the bioaccumulation of strontium by the fish caught at the different sample sites. 


\section{Conclusions}

In conclusion, this study has shown that manganese, nickel and strontium at elevated levels in the aquatic environment do accumulate in tissues of $C$. gariepinus. It bioaccumulated the highest amount of metals in its gills followed by liver, skin and muscle. The high metal concentrations detected in the gills and liver might indicate long-term (chronic) exposure of the fish to these metals.

Physiological stress resulting from chronic exposure could make a population less competitive, which could result in a gradual population decline or absence from a particular area. Both acute and chronic exposures to pollutants in the aquatic ecosystem can ultimately change the environment by altering the composition of the biota therein. The change in water quality poses the greatest threat to the aquatic environment's stability (Moore et al. 1991).

Physical and chemical factors such as $\mathrm{pH}$, temperature, salinity, dissolved oxygen, concentrations of soluble or insoluble organics, alkalinity and redox potential can all individually or synergistically increase the toxicity and bioavailability of metals to aquatic biota (Hellawell 1986). With this in mind it is vitally important that the amount of incoming pollutants (metals) be insignificant, so as not to cause accumulation of these metals in sediment, water and ultimately biota. However, if these factors undergo change and thereby influence the bioavailability of metals to biota, the effects on the environment and biota could be catastrophic. It is, therefore, imperative that metal contamination and physical and chemical factors are kept to a minimum by management with monitoring of sources as well as the aquatic environment.

\section{Acknowledgements}

We would like to thank the FRD and Institute for Water Quality Studies (IWQS) for financial assistance and the IWQS for chemical analyses of water and sediment samples. Furthermore, we would like to thank Gerhard Strydom and Pieter Kotze, at the time, staff at the Kruger National Park, for logistic assistance without which this project would not have been possible.

\section{References}

Avenant-Oldewage, A., H.M. Marx \& W.J. OldEWAGE (in press). Bioaccumulation of chromium, copper and iron in the organs and tissues of Clarias gariepinus in the Olifants River, Kruger National Park. Water S.A.

BECKER, C.D. 1990. Aquatic bioenvironmental studies: the Hanford experience 1944-84. Amsterdam: Elsevier. (Studies in environmental science, 39.)

Birge, W.J. \& J.A. BLACK. 1980. Aquatic toxicology of nickel. Pp. 349-366. In: NRIAGU, O.J. (ed.). Nickel in the environment. New York: John Wiley.

Cairns, J.(Jr)., A.G. Heath \& B.C. Parker. 1975. The effects of temperature upon the toxicity of chemicals to aquatic organisms. Hydrobiologia 47(1): 135-171.

Carraça, S., A. Ferreira \& J. Colmbra. 1990. Sr transfer factors between different levels in the trophic chain in two dams of Duoro River (Portugal). Water Research 24(12): 1497-1508.

Cross, F.A., L.H. Hardy, N.Y. JONES \& R.T. BaRBER. 1973. Relation between total body weight and concentrations of manganese, iron, copper, zinc, and mercury in white muscle of bluefish (Pomatomus saltatrix) and a bathyl-demersal fish Antimora rostrata. Journal of the Fisheries Research Board of Canada 30(9): 1287-1291.

Dallas, H.F. \& J.A. DAY. 1993. The effect of water quality variables on riverine ecosystems: $A$ review. Pretoria: Water Research Commission. (Water Research Commission; report no. TT 61/93).

Doudoroff, P. \& M. Katz. 1953. Critical review of literature on the toxicity of industrial wastes and their components to fish. II. The metals, as salts. Sewage and Industrial Wastes 25: 802-839.

DuFfus, J.H. 1980. Environmental toxicology, London: Edward Arnold.

Du Preez, H.H. \& J.G. Steyn. 1992. A preliminary investigation of the concentration of selected metals in the tissues and organs of the tigerfish (Hydrocynus vittatus) from the Olifants River, Kruger National Park, South Africa. Water SA 18(2): 131-136.

Du Preez, H.H., M. van DeR Merwe \& J.H.J. VAN VUREN. 1997. Bioaccumulation of selected metals in African catfish, Clarias gariepinus from the lower Olifants River, Mpumalanga, South Africa. Koedoe 40(1): 77-90.

Elwood, J.W., S.G. Hildebrand, \& J.J. BEAUCHAMP. 1976. Contribution of gut contents to the concentration and body burden of ele- 
ments in Tipula spp. from a spring-fed stream. Journal of the Fisheries Research Board of Canada 33: 1930-1938.

ENVIRONMENT CANADA. 1987. Canadian water quality guidelines: Prepared by the Task Force on water quality guidelines. 1 volume. Ottawa: The Canadian Council of Resource and Environment Ministers.

Faure, G. \& J.L. Powell. 1972. Strontium isotope geology. Berlin: Springer-Verlag.

FriberG, L., G.F. NordBerg \& V.B. Vouk. 1986. Handbook on the toxicology of metals. Volume II. Specific metals. Amsterdam: Elsevier.

GiesY, J.P.(JR). \& J.G, WienER. 1977. Frequency distributions of trace metal concentrations in five freshwater fishes. Transactions of the American Fisheries Society 106(4): 393-403.

HahNE, H.C.H. \& W. KROONTJE. 1973. Significance of $\mathrm{pH}$ and chloride concentration on behaviour of heavy metal pollutants: mercury (II), cadmium (II), zinc (II), and lead (II). Journal of Environmental Quality 2(4): 444-450.

HEATH, A.G. 1987. Water pollution and fish physiology. Boca Ranton: CRC Press.

Hellawell, J.M. 1986. Biological indicators of freshwater pollution and environmental management. London: Elsevier.

JenkINS, S.H. 1980. Mediterranean coastal pollution. Oxford: Pergamon Press.

Khalaf, A.N., A.R. Al-Jafery, B.Y. Khalid, S.S. Elias \& M.W. IshaQ. 1985. The patterns of accumulation of some heavy metals in Barbus grypus (Heckel) from a polluted river. Journal of Biological Science Research 16(2): 51-75.

KHANGAROT, B.S. \& P.K. RAY. 1990. Acute toxicity and toxic interaction of chromium and nickel to common guppy Poecilia reticulata (Peters). Bulletin of Environmental Contamination and Toxicology 44: 832-839.

Koli, A.K., S.S. Sandhu, W.T. Canty, K.L. Felix, R.J. ReEd \& R. Whitmore. 1978. Trace metals in some fish species of South Carolina. Bulletin of Environmental Contamination and Toxicology 20: 328-331.

Kotze, P., H.H. Du Preez \& J.H.J. Van Vuren. 1999. Bioaccumulation of copper and zinc in Oreochromis mossambicus and Clarias gariepinus, from the Olifants River, Mpumalanga, South Africa. Water SA 25(1): 99-110.

KWASNIK, G.M., R.J. VetTer \& G.J. Atchison. 1978. The uptake of manganese- 54 by green algae (Protococcoidal chlorella), Daphnia magna, and fathead minnows (Pimephales promelas). Hydrobiologia 59(3): 181-185.

MarX, H.M \& A. Avenant-Oldewage. 1998. A further investigation into bioaccumulation of lead and zinc in the organs and tissues of the African sharptooth-catfish, Clarias gariepinus from two localities in the Olifants River, Kruger National
Park. Koedoe 41(2): 27-42.

Moore, C.A., M. Van Veelen, P.J. Ashton \& R.D. WALMSLEY. 1991. Preliminary water quality guidelines for the Kruger National Park rivers. South African National Parks internal report. (Kruger National Park Rivers Research Programme; report no. 1).

MOORE, J.W. \& S. RAmamoorthy. 1984. Heavy metals in natural waters: Applied monitoring and impact assessment. New York: Springer-Verlag.

Moreau, G., C. Barbeau, J.J. Frenette, J. SaintONGE \& M. SimOnEAU. 1983. Zinc, manganese. and strontium in opercula and scales of brook trout (Savelinus fontinalis) as indicators of lake acidification. Canadian Journal of Fisheries and aquatic Science 40: 1685-1691.

NAGEL, R. 1991. Fish and environmental chemicals - a critical evaluation of tests. Pp. 147-156. Im: Braunbeck, T., W. Hanke \& H. Segner (eds.). Fish: ecotoxicology and ecophysiology. Proceedings of an International Symposium, Heidelberg, Germany.

Pagenkopf, G.K. \& D.R. Neumann. 1974. Lead concentrations in native trout. Bulletin of Environmental Contamination and Toxicology 12: $70-75$.

Phillips, G.R. \& R.C. Russo. 1978. Metal bioaccumulation in fishes and aquatic invertebrates: a literature review. Duluth, Minnesota: Environmental Protection Agency. (MN-EPA-600/3-78103.)

Pickering, Q.H. \& C. Henderson. 1966. The acute toxicity of some heavy metals to different species of warmwater fishes. Air and Water Pollution International Journal 10: 453-463.

Preston, A., D.F. Jefferies \& J.W.R. Dutton. 1967. The concentration of caesium-137 and strontium-90 in the flesh of brown trout taken from rivers and lakes in the British Isles between 1961 and 1966: The variables determining the concentrations and their use in radiological assessments. Water Research 1: 475-496.

Prosi, F. 1979. Heavy metals in aquatic organisms. Pp. 271-323. In: Förstner, U. \& G.T.W. WITTMANN (eds.). Metal pollution in the aquatic environment. Berlin: Springer Verlag.

RADTKE, R.L. 1989. Strontium-calcium concentration ratios in fish otoliths as environmental indicators. Comparative Biochemistry and Physiology $92 \mathrm{~A}(2)$ : 189-193.

RAY, S. 1978. Bioaccumulation of lead in Atlantic salmon Salmo salar: Bulletin of Environmental Contamination and Toxicology 19(5): 631-636.

SChiffman, R.H. 1961. A perfusion study of the movement of strontium across the gills of rainbow trout (Salmo gairdnerii). Biological Bulletin 120(1): 110-117.

Seymore, T., H.H, Du Preez \& J.H.J. Van Vuren. 1995. Manganese, lead and strontium bioaccu- 
mulation in the tissues of the yellowfish, Barbus marequensis from the lower Olifants River, Eastern Transvaal. Water SA 21(2): 159-172.

Siymore, T., H.H. Du Preez, J.H.J. Van Vuren, A. DeAcon \& G. Strydom. 1994. Variations in selected water quality variables and metal concentrations in the sediment of the lower Olifants and Selati Rivers, South Africa. Koedoe 37(2): $1-18$.

SNODGRass, W.J. 1980. Distribution and behaviour of nickel in the aquatic environment. Pp. 203-274. In: Nriagu, O.J. (ed.). Nickel in the environment. NewYork: John Wiley.

StagG, R.M. \& T.J. Shuttleworth. 1982. The accumulation of copper in Platichthys flesus L. and its effects on plasma electrolyte concentrations. Journal of Fish Biology 20: 491-500.

Sunderman, F.W. \& A. Oskarsson. 1991. Nickel. Pp. 1101-1126. In: Merian, E. (ed.). Metals and their compounds in the environment. Occurrence, analysis and biological relevance. New York: VCH.

Tuälve, H., J. Gottofrey \& K. Borg. 1988. Bioaccumulation, distribution and retention of ${ }^{63} \mathrm{Ni}^{2+}$ in the brown trout (Salmo trutta). Water Research 22(9): 1129-1136.

VAN DER MERWE, M. 1992. Aspects of heavy metal concentration in the Olifants River, Kruger
National Park, and the effect of copper on the haematology of Clarias gariepinus (Clariidae). M.Sc. thesis, Rand Afrikaans University, Johannesburg.

VAn Loon, J.C. 1980. Analytical Atomic Absorption Spectroscopy. Selected methods. New York: Academic Press.

Veith, G.D., D.L. Defoe \& B.V. Bergstedt. 1979. Measuring and estimating the bioconcentration factor of chemicals in fish. Journal of the Fisheries Research Board of Canada 36: 1040-1048.

Wetzel, R.G. 1983. Limnology. $2^{\text {nd }}$ ed. New York: Saunders College.

WiCKLUND, G.A. 1991. Cadmium and zinc kinetics in fish: Studies on water-borne ${ }^{109} \mathrm{Cd}$ and ${ }^{65} \mathrm{Zn}$ turnover and intracellular distribution in minnows, Phoxinus phoxinus. Pharmacology and Toxicology 69: 485-491.

Wiener, J.G. \& J.P. Giesy (JR). 1979. Concentrations of $\mathrm{Cd}, \mathrm{Cu}, \mathrm{Mn}, \mathrm{Pb}$ and $\mathrm{Zn}$ in fishes in a highly organic softwater pond. Journal of the Fisheries Research Board of Canada 36: 270-279.

Wren, C.D., H.R. Maccremmon \& B.R. Loescher. 1983. Examination of bioaccumulation and biomagnification of metals in a precambrian shield lake. Water, Air; and Soil Pollution 19: 277-291. 